but certain members represent deceased kings : it is as if in the House of Lords the present Duke of Wellington sat as the representative of 'The Duke'. Dr. Gluckman is opposed to the abolition of these titles on the ground of economy: they are 'Lozi history' and cherished as such : and to retain them does not cost a great deal. The Lozi have their national treasury from which the native officials are paid; the Pim Commission complained that the expenditure on this head is much too high and that many officials are superfluous. While Dr. Gluckman does not advocate any elimination of 'titles' at present, he warns the Lozi that the keeping up of numerous officials means not only low salaries but also a retardation of social services.

A third subject investigated by Dr. Gluckman is the malapa-a Sotho word which originally denoted the inclosures around Sotho huts but which now among the Lozi is applied to the king's storehouses. The people were all attached to one or other of the malapa, each of which was in charge of a sikombwa (" steward '). The tribute brought to the king in old days was stored there; people visiting the capital could always find food at the storehouse to which they were attached. With the abolition of tribute, goods no longer flow in any quantity into and out of the capital, and visitors on legal or other business have difficulty in finding shelter and food. Dr. Gluckman makes the sensible suggestion that the malapa be rebuilt as rest- and eating-houses and that the 'stewards' be again put in charge of them.

We have not been able, within the compass of a single Note, to touch on all the interesting points of this memorandum. Here is good testimony of the value of a specifically trained and independent mind applied to difficult administrative questions. We shall watch with interest the outcome of the proposals.

\title{
Birth-rate in Belgian Congo
}

Dr. G. A.Schwers of Coquilhatville examines in Aequatoria ( 7 e année, 1944, numéro 3 ) factors making for a diminished birth-rate in some regions of Belgian Congo. He is not satisfied as to some of the alleged causes, such as malnutrition. He is open to believe that certain toxic elements like hydrocyanic acid in manioc have some effect on fecundity, but this requires further study. Social factors certainly operate-breakdown of manners and customs, premature emancipation of women, and so on. Apathy, loss of racial pride-all that he calls psychic traumatism-certainly has a great part to play. But Dr. Schwers will not consider that the problem is on the way to solution until answers are found to three questions: (I) Do there exist among the regressive tribes, and only among them, anatomical lesions or functional disorders affecting the sexual cells and not attributable to any known toxic infection? (2) If those lesions exist and if they accompany psychic traumatism, what is the link between these two phenomena? How do they combine their effects to bring about a declining birth-rate? Is it possible to establish between them relations of cause and effect, or do they both depend upon a common factor? (3) By what mechanism do certain tribes resist social disintegration and the physiological decay which sweep away neighbouring tribes? Dr. Schwers has no final answer to give to these questions; but his examination of some 39,000 persons of the Nkundo tribe and comparison with some other groups of the same region suggest a partial reply. At the time of his inquiry one section of the Nkundo had little contact with Europeans; the men did not furnish labour to plantations or for the roads. Apparently they were a vigorous, sober, sufficiently nourished people, conservative in their attitude, and only to a very small degtee afflicted by venereal disease. They ought to have exhibited a normal fecundity; on the contrary the average worked out at about one birth to every three adult women. There was something peculiar about this state of affairs: here and there a village still prosperous alongside others on the brink of disappearing; an abrupt line of demarcation between the unprolific Nkundo and their fruitful neighbours living in identical conditions. Puzzled by this paradoxical dénatalité, Dr. Schwers set himself 
to find the cause and discovered that among the regressive clans from 8 to 13 per cent. of the adult males were afflicted with testicular atrophy and that cryptorchids were in excessive numbers, mounting in some villages to 25 per cent. of the boys, some 60 per cent. of these being affected before they were four years of age. He found mathematical correlation between these two facts and sterility. "Nous avions donc trouvé, dans le regard de la migration testiculaire un nouveau facteur, incontestable, de dénatalité, caractéristique des tribus décadentes à mours "primitives".' Dr. Schwers is awaiting confirmation by the laboratory of his results, but claims on the strength of clinical observations to have established ' une théorie endocrinienne de la dénatalité'. He gives an affirmative answer to the first of his questions: "il existe chez les Nkundo des lésions anatomiques et troubles fonctionnels spéciaux de l'appareil endocrinien, retentissant sur la sphère sexuelle: ils éclairent le mécanisme de la dénatalité et expliquent l'apathie et la résignation de ceux qui en sont frappés'. 'This physical condition cannot be attributed to any known infectious disease; and it is very doubtful whether it is the consequence of malnutrition. It coincides with moral disturbance and social instability; but more study is required before the link between the two series of factors can be recognized.

\section{The Hamitic Migrations}

For students of culture contact the Hamitic peoples of the lacustrine region are an unfailing source of interest. We would draw their attention to an article by Eugène Simons, a territorial administrator, in Bulletin des Juridictions indigènes et du Droit coutumier congolais for November-December 1944. It is generally supposed in Urundi that the infiltration of Hamitic pastoral people, Batutsi and Bahima, took place when the country was occupied by Bantu agriculturists, the Bahutu. By reason of their superior intelligence, their political spirit, and their possession of cattle, the new-comers established their supremacy, but adopted the manners and customs and, it is supposed, also the language of the subject Bahutu. Kitundi is unquestionably a Bantu language and no difference can be discerned between the speech of the four elements of the population, Batutsi, Bahima, Bahutu, and Batwa. Among other problems, this one calls for an answer: If the Hamites introduced cattle previously unknown to the Bantu of that region, how comes it about that the vocabulary relating to cattle is Bantu and not Hamitic? One might expect Hamitic words or Hamitic roots bantuized; but it is not so. (We notice one word in M. Simons' vocabulary, viz. ente = bœuf, vache, which does not appear to be Bantu, but is common to several Nyanza and Semliki languages.)

We do not know the original home of these Hamitic peoples not when they migrated thence. We do know that they inhabited and ruled the kingdom of Kitara between Lakes Victoria, Albert, and Edward. It would appear certain that at one time that country became over-populated and many tribes, Bantu and Hamitic, migrated. Some of the Hamites went south into Ruanda and Urundi and others went north-north-west, over the Semliki to the Ituri. The ethnical type of the Hamites in Ruanda is very pure; in Urundi it is less pure among the Batutsi than among the Bahima. In the Ituri region the Hamites are much mixed with Babira, Walendu, and Wanande. Their name is Bahema; their anguage is almost identical with Kirundi and there are other points of resemblance to the Bahima of Urundi. That all these Hamites have a common origin is not to be doubted. But what is to be said of their relationship with the Bahutu? M. Simons refers to two hypotheses which he rejects: (I) the Bahema of the Ituri first migrated south to RuandaUrundi and then north to the Ituri; (2) the Bahutu and perhaps the Batwa penetrated into Ruanda-Urundi with the Batutsi. He adopts as most probable a third theory: The Bahutu lived in the Kitara kingdom until some time before 1650 when for some reason unknown they marched south and occupied Ruanda-Urundi. Later, part of the Batutsi followed with 